\title{
Identification of Soluble Epoxide Hydrolase Inhibitors from the Seeds of Passiflora edulis Cultivated in Vietnam
}

\author{
To Dao Cuong ${ }^{1,2,3, *}$, Hoang Thi Ngoc Anh ${ }^{1}$, Tran Thu Huong', Pham Ngoc Khanh ${ }^{1}$, Vu Thi Ha ${ }^{1}$, Tran Manh Hung ${ }^{5}$, \\ Young Ho Kim ${ }^{6}$, and Nguyen Manh Cuong ${ }^{1,4, *}$ \\ ${ }^{1}$ Institute of Natural Products Chemistry, Vietnam Academy of Science and Technology (VAST), \\ 18 Hoang Quoc Viet, Cau Giay, Hanoi, Vietnam \\ ${ }^{2}$ Faculty of Pharmacy, Phenikaa University, Yen Nghia, Ha Dong, Hanoi 12116, Vietnam \\ ${ }^{3}$ Phenikaa Research and Technology Institute (PRATI), A\&A Green Phoenix Group JSC, \\ No.167 Hoang Ngan, Trung Hoa, Cau Giay, Hanoi 11313, Vietnam \\ ${ }^{4}$ Graduate University of Science and Technology, Vietnam Academy of Science and Technology, Hanoi, 100803, Vietnam \\ ${ }^{5}$ Department of Biomedical Sciences, Institute for Research and Executive Education (VNUK), The University of Danang, \\ 158 A Le Loi Street, Hai Chau district, Da Nang 551000, Vietnam \\ ${ }^{6}$ College of Pharmacy, Chungnam National University, Daejeon 34134, Republic of Korea
}

\begin{abstract}
Soluble epoxide hydrolases (sEH) are enzymes present in all living organisms, metabolize epoxy fatty acids to 1,2-diols. sEH in the metabolism of polyunsaturated fatty acids plays a key role in inflammation. In addition, the endogenous lipid mediators in cardiovascular disease are also broken down to diols by the action of sEH that enhanced cardiovascular protection. In this study, sEH inhibitory guided fractionation led to the isolation of five phenolic compounds trans-resveratrol (1), trans-piceatannol (2), sulfuretin (3), (+)-balanophonin (4), and cassigarol E (5) from the ethanol extract of the seeds of Passiflora edulis Sims cultivated in Vietnam. The chemical structures of isolated compounds were determined by the interpretation of NMR spectral data, mass spectra, and comparison with data from the literature. The soluble epoxide hydrolase ( $\mathrm{sEH}$ ) inhibitory activity of isolated compounds was evaluated. Among them, trans-piceatannol (2) showed the most potent inhibitory activity on $\mathrm{sEH}$ with an $\mathrm{IC}_{50}$ value of $3.4 \mu \mathrm{M}$. This study marks the first time that sulfuretin (3) was isolated from Passiflora edulis as well as (+)-balanophonin (4), and cassigarol E (5) were isolated from Passiflora genus.
\end{abstract}

Keywords - Passiflora edulis, Passifloraceae, Phenolic, Stilbene, sEH

\section{Introduction}

Soluble epoxide hydrolase (sEH, EC 3.3.2.10) is the major enzyme responsible for the hydrolysis of epoxy fatty acids (EpFAs) to their corresponding vicinal diols in humans and other mammals. ${ }^{1}$ These EpFAs include the epoxides of linoleic, arachidonic, eicosapentaenoic, and docosahexaenoic acid that are produced primarily by cytochrome P450s. These natural molecules are pleiotropic endogenous mediators with key functions in inflamma-

\footnotetext{
*Author for correspondence

To Dao Cuong, Faculty of Pharmacy, Phenikaa University, Yen Nghia, Ha Dong, Hanoi 12116, Vietnam.

Tel: +84-971-886-989; E-mail: cuong.todao@phenikaa-uni.edu.vn
}

Nguyen Manh Cuong, Institute of Natural Products Chemistry, Vietnam Academy of Science and Technology (VAST), 18 Hoang Quoc Viet, Cau Giay, Hanoi, Vietnam.

Tel: +84-24-3791-1812; E-mail: nmcuong inpc@yahoo.com.vn tion, ${ }^{1}$ pain, ${ }^{2}$ and blood pressure regulation. ${ }^{3}$ Increasing the levels of endogenous EpFAs by inhibiting sEH has been shown to block and resolve inflammation, ${ }^{4}$ reduce pain, ${ }^{2}$ lower blood pressure, and prevent cardiovascular diseases. ${ }^{5}$ To overcome these problems, finding new inhibitors from natural plants has been investigated. A few sEH inhibitors from natural products have been identified. The results showed that natural compounds found to inhibit sEH were diverse including biflavonoids, ${ }^{6}$ selaginellin, ${ }^{7}$ stilbenes, ${ }^{8}$ anthraquinone derivatives, ${ }^{9}$ carbazole-type alkaloids (isomahanine, bisisomahanine) ${ }^{10}$ alkylphloroglucinol derivatives, and triterpenoids. ${ }^{11}$ These results encourage us to continue our studies in discovery of sEH inhibitors from natural sources.

From our screening results, we found that the ethanol extract of Passiflora edulis Sims had appreciable inhibitory activity. Passiflora edulis Sims (Passifloraceae), a 
popular tropical fruit throughout the world, is usually used for juice production, ${ }^{12}$ and widely cultivated in South America, Africa, and Asia. In Vietnam, P. edulis is popularly cultivated in Tay Nguyen, Nghe An and Son La with areas of over ten thousand hectares. P. edulis was found to possess biological activities including antiinflammatory, ${ }^{13}$ antihypertensive, ${ }^{14}$ anti-oxidant, ${ }^{15}$ antitumor, ${ }^{16}$ anti-anxiety, ${ }^{17}$ antifungal, ${ }^{18}$ and found to inhibit melanogenesis and promote collagen synthesis. ${ }^{19}$ Previous studies on chemical constituents of $P$. edulis showed the presence of triterpenoids, ${ }^{20}$ flavonoids,${ }^{21}$ alkaloids, ${ }^{22}$ carotenoids ${ }^{23}$ stilbenoids, ${ }^{19,24}$ oil, and tocopherols. ${ }^{25}$ In spite of the number of studies that have been performed, ${ }^{19,24,25}$ there has been no investigation of chemical constituents and sEH inhibitory activity of $P$. edulis seeds cultivated in Vietnam. Therefore, this paper described the isolation and structural elucidation of these compounds as well as the evaluation of their inhibitory activity on $\mathrm{sEH}$.

\section{Experimental}

General experimental procedures $-{ }^{1} \mathrm{H}-\mathrm{NMR}$ (500 $\mathrm{MHz})$ and ${ }^{13} \mathrm{C}-\mathrm{NMR}(125 \mathrm{MHz})$ were measured on a Bruker Avance $500 \mathrm{MHz}$ spectrometer. ESI-MS was obtained from a Varian FT-MS spectrometer and MicroQTOF III (Bruker Daltonics, Ettlingen Germany). Optical rotations were measured on P-2000 polarimeter (JASCO, Tokyo, Japan). Column chromatography was carried out on silica gel ( $\mathrm{Si} 60 \mathrm{~F}_{254}, 40-63$ mesh, Merck, St. Louis, MO, USA). All solvents were redistilled before use. Precoated TLC plates $\left(\mathrm{Si} 60 \mathrm{~F}_{254}\right)$ were used for analytical purposes. Compounds were visualized under UV radiation $(254,365 \mathrm{~nm})$ and by spraying plates with $10 \% \mathrm{H}_{2} \mathrm{SO}_{4}$ followed by heating with a heat gun.

Plant materials - The seeds of Passiflora edulis Sims were provided by Nafoods Group JSC (Nghe An Province, Vietnam) in 2016 and identified by botanist Dr. Nguyen Quoc Binh, Vietnam National Museum of Nature, VAST, Hanoi, Vietnam. A voucher specimen (C573) was deposited in the Herbarium of the Institute of Natural Products Chemistry, VAST, Vietnam.

Extraction and isolation - The dried powdered seeds $(1.0 \mathrm{~kg})$ of $P$. edulis were extracted three times with $n$ hexane $(3 \times 4.0 \mathrm{~L})$ at room temperature for 3 days, filtered, and then concentrated under decreased pressure to give $n$-hexane extract $(200 \mathrm{~g})$ and residue. The dried residue $(700 \mathrm{~g})$ was then extracted three times with ethanol $(3 \times 3.0 \mathrm{~L})$ by sonication for 6 hours. The ethanol extract $(60 \mathrm{~g})$ was suspended in hot-water $(0.3 \mathrm{~L})$ and partitioned with dichloromethane $\left(\mathrm{CH}_{2} \mathrm{Cl}_{2}, 3 \times 3.0 \mathrm{~L}\right)$ and ethyl acetate (EtOAc, $3 \times 3.0 \mathrm{~L}$ ) successively. The resulting fraction was concentrated under decreased pressure to give $\mathrm{CH}_{2} \mathrm{Cl}_{2}(5.2 \mathrm{~g})$ and EtOAc $(20 \mathrm{~g})$ fractions, respectively. By the guided-fractionation activity, the EtOAc soluble fraction was chromatographed on a silica gel column chromatography (CC) eluting with a gradient of $\mathrm{CHCl}_{3}-\mathrm{MeOH}(20: 1$ to $0: 1)$ to afford eight fractions (Fr. E1 to Fr. E8). Fraction E3 ( $820 \mathrm{mg}$ ) was subjected on a silica gel CC eluting with a gradient of $n$-hexane-acetone (4:1 to $0: 1)$ to afford compounds $1(6.2 \mathrm{mg})$ and 2 (200 $\mathrm{mg})$. Fraction E4 ( $3.5 \mathrm{~g})$ was also subjected to silica gel $\mathrm{CC}$ eluting with a gradient of $\mathrm{CHCl}_{3}$-acetone (4:1 to $0: 1$ ) to afford six sub-fractions (E4.1 to E4.6). Compounds 3 $(15.8 \mathrm{mg})$ and $\mathbf{4}(16.2 \mathrm{mg})$ were obtained from sub-fraction E4.3 $(250 \mathrm{mg}$ ) by using C18-RP silica gel CC and eluting with a gradient of $\mathrm{MeOH}-\mathrm{H}_{2} \mathrm{O}$ (1:2 to 2:1). Fraction E5 $(6.5 \mathrm{~g})$ was also subjected to silica gel $\mathrm{CC}$ eluting with a gradient of $\mathrm{CHCl}_{3}-\mathrm{MeOH}$ (5:1 to 0:1) to afford eight subfractions (E5.1 to E5.8). The sub-fraction E5.6 $(320 \mathrm{mg})$ was further subjected to $\mathrm{C} 18-\mathrm{RP}$ silica gel $\mathrm{CC}$, eluted with a gradient of $\mathrm{MeOH}-\mathrm{H}_{2} \mathrm{O}$ (1:3 to 1:1) to afford compound $\mathbf{5}(10.2 \mathrm{mg})$.

Trans-resveratrol (1) - Ivory amorphous powder; ${ }^{1} \mathrm{H}$ NMR $\left(500 \mathrm{MHz}\right.$, Methanol- $\left.d_{4}\right) \delta_{\mathrm{H}}(\mathrm{ppm}): 6.47(2 \mathrm{H}, \mathrm{d}$, $J=2.0 \mathrm{~Hz}, \mathrm{H}-2 / \mathrm{H}-6), 6.18(1 \mathrm{H}, \mathrm{t}, J=2.0 \mathrm{~Hz}, \mathrm{H}-4), 7.36$ $\left(2 \mathrm{H}, \mathrm{d}, J=8.5 \mathrm{~Hz}, \mathrm{H}-2^{\prime} / \mathrm{H}-6^{\prime}\right), 6.78(2 \mathrm{H}, \mathrm{d}, J=8.5 \mathrm{~Hz}, \mathrm{H}-$ $\left.3^{\prime} / \mathrm{H}-5^{\prime}\right), 6.97(1 \mathrm{H}, \mathrm{d}, J=16.0 \mathrm{~Hz}, \mathrm{H}-8), 6.81(1 \mathrm{H}, \mathrm{d}$, $J=16.0 \mathrm{~Hz}, \mathrm{H}-7) ;{ }^{13} \mathrm{C}-\mathrm{NMR}\left(125 \mathrm{MHz}\right.$, Methanol- $\left.d_{4}\right) \delta_{\mathrm{C}}$ (ppm): 159.6 (C-3/C-5), 158.3 (C-4), 141.3 (C-1), 130.4 (C-1'), 129.3 (C-8), 128.7 (C-2'/C-6'), 127.0 (C-7), 116.4 (C-3'/C-5'), 105.7 (C-2/C-6), 102.6 (C-4); ESI-MS m/z $229.09[\mathrm{M}+\mathrm{H}]^{+}\left(\mathrm{Calcd}\right.$. for $\left.\mathrm{C}_{14} \mathrm{H}_{12} \mathrm{O}_{3}\right)$.

Trans-piceatannol (2) - Ivory amorphous powder; ${ }^{1} \mathrm{H}-$ NMR $\left(500 \mathrm{MHz}\right.$, Acetone- $\left.d_{6}\right) \delta_{\mathrm{H}}(\mathrm{ppm}): 8.36(2 \mathrm{H}, \mathrm{s}, 3 / 5-$ $\mathrm{OH}), 8.16(1 \mathrm{H}$, br s, 4'-OH), $8.06(1 \mathrm{H}$, br s, 3'-OH), 7.07 $\left(1 \mathrm{H}, \mathrm{d}, J=2.0 \mathrm{~Hz}, \mathrm{H}-2^{\prime}\right), 6.93(1 \mathrm{H}, \mathrm{d}, J=16.5 \mathrm{~Hz}, \mathrm{H}-8)$, $6.89\left(1 \mathrm{H}, \mathrm{dd}, J=8.5,2.0 \mathrm{~Hz}, \mathrm{H}-6^{\prime}\right), 6.82(1 \mathrm{H}, \mathrm{d}, J=8.5$ $\left.\mathrm{Hz}, \mathrm{H}-5^{\prime}\right), 6.81(1 \mathrm{H}, \mathrm{d}, J=16.5 \mathrm{~Hz}, \mathrm{H}-7), 6.53(2 \mathrm{H}, \mathrm{d}$, $J=2.0 \mathrm{~Hz}, \mathrm{H}-2 / 6), 6.25(1 \mathrm{H}, \mathrm{s}, \mathrm{H}-4) ;{ }^{13} \mathrm{C}-\mathrm{NMR}(125$ $\mathrm{MHz}$, Acetone- $\left.d_{6}\right) \delta_{\mathrm{C}}(\mathrm{ppm}): 159.5(\mathrm{C}-3 / \mathrm{C}-5), 146.0(\mathrm{C}-$ 3'/C-4'), 140.7 (C-1), 130.5 (C-1'), 129.2 (C-8), 126.8 (C7), 119.8 (C-6'), 116.1 (C-5'), 113.7 (C-2'), 105.5 (C-2/C6), 102.6 (C-4); ESI-MS m/z $245.08[\mathrm{M}+\mathrm{H}]^{+}$(Calcd. for $\mathrm{C}_{14} \mathrm{H}_{12} \mathrm{O}_{4}$ ).

Sulfuretin (3) - Yellow amorphous solid; ${ }^{1} \mathrm{H}-\mathrm{NMR}$ $\left(500 \mathrm{MHz}\right.$, Methanol- $\left.d_{4}\right) \delta_{\mathrm{H}}(\mathrm{ppm}): 7.63(1 \mathrm{H}, \mathrm{d}, J=8.5$ $\mathrm{Hz}, \mathrm{H}-5), 7.54(1 \mathrm{H}, \mathrm{d}, J=2.0 \mathrm{~Hz}, \mathrm{H}-8), 7.26(1 \mathrm{H}, \mathrm{dd}$, $J=8.5,2.0 \mathrm{~Hz}, \mathrm{H}-6), 6.86\left(1 \mathrm{H}, \mathrm{d}, J=8.0 \mathrm{~Hz}, \mathrm{H}-5^{\prime}\right), 6.73$ $\left(1 \mathrm{H}, \mathrm{dd}, J=8.0,2.0 \mathrm{~Hz}, \mathrm{H}-6^{\prime}\right), 6.72(1 \mathrm{H}, \mathrm{d}, J=2.0 \mathrm{~Hz}, \mathrm{H}-$ $\left.2^{\prime}\right), 6.71(1 \mathrm{H}, \mathrm{s}, \mathrm{H}-2) ;{ }^{13} \mathrm{C}-\mathrm{NMR}\left(125 \mathrm{MHz}\right.$, Methanol- $\left.d_{4}\right)$ 
$\delta_{\mathrm{C}}(\mathrm{ppm}): 184.5(\mathrm{C}-4), 169.8(\mathrm{C}-7), 168.4$ (C-9), 149.3 (C-4'), 147.7 (C-3), 146.7 (C-3'), 126.8 (C-5), 126.3 (C6'), 125.5 (C-1'), 118.9 (C-2'), 116.7 (C-5'), 114.8 (C-10), 114.6 (C-6), 114.1 (C-2), 99.3 (C-8); ESI-MS m/z: 271.06 $[\mathrm{M}+\mathrm{H}]^{+}\left(\right.$Calcd. for $\left.\mathrm{C}_{15} \mathrm{H}_{10} \mathrm{O}_{5}\right)$.

(+)-Balanophonin (4) - Yellow amorphous powder; $[\alpha]_{\mathrm{D}}^{25}+16.3^{\circ}(c 0.05, \mathrm{MeOH})$; $^{1} \mathrm{H}-\mathrm{NMR}(500 \mathrm{MHz}$, Methanol$\left.d_{4}\right) \delta_{\mathrm{H}}: 9.60\left(1 \mathrm{H}, \mathrm{d}, J=8.0 \mathrm{~Hz}, \mathrm{H}-9^{\prime}\right), 7.61(1 \mathrm{H}, \mathrm{d}$, $\left.J=15.5 \mathrm{~Hz}, \mathrm{H}-7^{\prime}\right), 7.31$ (1H, s, H-6'), $7.25\left(1 \mathrm{H}, \mathrm{s}, \mathrm{H}-2^{\prime}\right)$, $6.97(1 \mathrm{H}, \mathrm{s}, \mathrm{H}-2), 6.85(1 \mathrm{H}, \mathrm{d}, J=8.0 \mathrm{~Hz}, \mathrm{H}-5), 6.80(1 \mathrm{H}$, d, $J=8.0, \mathrm{H}-6), 6.70\left(1 \mathrm{H}, \mathrm{dd}, J=15.5,8.0 \mathrm{~Hz}, \mathrm{H}-8^{\prime}\right)$, $5.63(1 \mathrm{H}, \mathrm{d}, J=6.5 \mathrm{~Hz}, \mathrm{H}-7), 3.92\left(3 \mathrm{H}, \mathrm{s}, 3^{\prime}-\mathrm{OCH}_{3}\right)$, 3.91-3.87 (2H, m, H-9), $3.84\left(3 \mathrm{H}, \mathrm{s}, 3-\mathrm{OCH}_{3}\right), 3.59(1 \mathrm{H}$, q, $J=6.5 \mathrm{~Hz}, \mathrm{H}-8) ;{ }^{13} \mathrm{C}-\mathrm{NMR}\left(125 \mathrm{MHz}\right.$, Methanol- $\left.d_{4}\right)$ $\delta_{\mathrm{C}}(\mathrm{ppm}): 196.1\left(\mathrm{C}-9^{\prime}\right), 156.8$ (C-4'), 156.1 (C-3'), 152.9 (C-4), 149.2 (C-3), 146.0 (C-7'), 133.9 (C-1), 131.3 (C-5), 129.6 (C-1'), 127.1 (C-8'), 120.0 (C-6), 119.8 (C-6'), 116.2 (C-5), 114.3 (C-2'), 110.6 (C-2), 90.1 (C-7), 64.5 (C-9), $56.8\left(3-\mathrm{OCH}_{3}\right), 56.4\left(3^{\prime}-\mathrm{OCH}_{3}\right), 54.6(\mathrm{C}-8)$; ESI-MS m/z: $357.14[\mathrm{M}+\mathrm{H}]^{+}$(Calcd. for $\left.\mathrm{C}_{20} \mathrm{H}_{20} \mathrm{O}_{6}\right)$.

Cassigarol E (5) - Brown amorphous powder; $[\alpha]_{D}^{25}$ $-56.4^{\circ}$ (c 0.12, MeOH); ${ }^{1} \mathrm{H}-\mathrm{NMR}(500 \mathrm{MHz}$, Methanol$\left.d_{4}\right) \delta_{\mathrm{H}}(\mathrm{ppm}): 7.15(1 \mathrm{H}, \mathrm{d}, J=2.0 \mathrm{~Hz}, \mathrm{H}-2), 7.09(1 \mathrm{H}, \mathrm{dd}$, $J=8.5,2.0 \mathrm{~Hz}, \mathrm{H}-6), 6.99(1 \mathrm{H}, \mathrm{d}, J=16.0 \mathrm{~Hz}, \mathrm{H}-7), 6.96$ $(1 \mathrm{H}, \mathrm{d}, J=8.5 \mathrm{~Hz}, \mathrm{H}-5), 6.88(1 \mathrm{H}, \mathrm{d}, J=16.0 \mathrm{~Hz}, \mathrm{H}-8)$, $6.68\left(1 \mathrm{H}, \mathrm{d}, J=2.0 \mathrm{~Hz}, \mathrm{H}-2^{\prime}\right), 6.67(1 \mathrm{H}, \mathrm{d}, J=8.5 \mathrm{~Hz}, \mathrm{H}-$ $\left.5^{\prime}\right), 6.50\left(1 \mathrm{H}, \mathrm{dd}, J=8.5,2.0 \mathrm{~Hz}, \mathrm{H}-6^{\prime}\right), 6.48$ (2H, overlap, H-12/H-12'), 6.19 (1H, t, $J=2.0 \mathrm{~Hz}, \mathrm{H}-14$ '), 6.17 (1H, t, $\left.J=2.0 \mathrm{~Hz}, \mathrm{H}-10^{\prime}\right), 6.12(2 \mathrm{H}, \mathrm{d}, J=2.0 \mathrm{~Hz}, \mathrm{H}-10 / \mathrm{H}-14)$, $4.75\left(2 \mathrm{H}, \mathrm{d}, J=2.5 \mathrm{~Hz}, \mathrm{H}-7^{\prime} / \mathrm{H}-8^{\prime}\right) ;{ }^{13} \mathrm{C}-\mathrm{NMR}(125 \mathrm{MHz}$, Methanol- $\left.d_{4}\right) \delta_{\mathrm{C}}(\mathrm{ppm}): 159.6\left(\mathrm{C}-11 / \mathrm{C}-11^{\prime}\right), 159.2(\mathrm{C}-13 /$ C-13'), 146.6 (C-4'), 146.1 (C-3'), 145.4 (C-4), 145.0 (C3), 141.0 (C-9), 140.1 (C-9'), 132.6 (C-1), 129.4 (C-7), 129.0 (C-1'), 128.4 (C-8), 121.0 (C-6'), 120.7 (C-6), 118.1 (C-5), 115.9 (C-2), 115.8 (C-5'), 115.6 (C-2'), 107.4 (C10'/C-14'), 105.9 (C-10/C-14), 103.6 (C-12'), 102.9 (C12), 82.2 (C-8'), 81.8 (C-7'); ESI-MS $m / z$ : 487.13 [M+ $\mathrm{H}]^{+}$(Calcd. for $\mathrm{C}_{28} \mathrm{H}_{22} \mathrm{O}_{8}$ ).

sEH Inhibitory Activity Assay - The sEH assay was performed as described previously. ${ }^{8} 11$ Briefly, $130 \mu \mathrm{L}$ of $\mathrm{sEH}$ in $25.0 \mathrm{mM}$ Bis-Tris-HCl buffer (pH 7.0) and 20.0 $\mu \mathrm{L}$ of the compounds $(1-0.06 \mathrm{mM}$ concentration) diluted in methanol, were added in 96-well plate, to which 50.0 $\mu \mathrm{L}$ of $20.0 \mu \mathrm{M}$ PHOME was added in the mixture. After initiating the enzyme reaction at $37^{\circ} \mathrm{C}$, the products by hydrolysis of the substrate were monitored at excitation and emission of 330 and $465 \mathrm{~nm}$ for one hour.

Inhibitory activity $(\%)=100-\left[\left(\mathrm{C}_{40}-\mathrm{C}_{0}\right)-\left(\mathrm{S}_{40}-\mathrm{S}_{0}\right) /\right.$ $\left.\left(\mathrm{C}_{40}-\mathrm{C}_{0}\right)\right] \times 100$

where $\mathrm{C}_{40}$ and $\mathrm{S}_{40}$ were the fluorescence of the control and inhibitor, respectively, after $40 \mathrm{~min}, \mathrm{~S}_{0}$ and $\mathrm{C}_{0}$ is the fluorescence of inhibitor and control, respectively, at 0 min. 12-(3-adamantan-1-yl-ureido)dodecanoic acid (AUDA) was used as a positive control.

Statistical Analysis - sEH inhibitory activity assay was performed in triplicate. The results are presented as the means \pm standard error of the mean.

\section{Result and Discussion}

After removing the oil (vegetable oil) from the seeds of $P$. edulis by $n$-hexane, the residue was extracted with ethanol to obtain ethanol extract. In the search for $\mathrm{sEH}$ inhibitors from natural sources, we found that the ethanol extract of the seeds of $P$. edulis inhibited $64.7 \%$ of sEH activity at a concentration of $37.5 \mu \mathrm{g} / \mathrm{mL}$. This extract was then partitioned with dichloromethane $\left(\mathrm{CH}_{2} \mathrm{Cl}_{2}\right)$, ethyl acetate (EtOAc) fractions and aqueous residue. In the preliminary experiment, we tested the inhibitory activity of these fractions at 37.5, 75.0 and $150.0 \mu \mathrm{g} / \mathrm{mL}$.

Based on the results in Table $1, \mathrm{CH}_{2} \mathrm{Cl}_{2}$ - soluble fraction showed $91.8 \%$ inhibition at the concentration of $37.5 \mu \mathrm{g} /$ $\mathrm{mL}$, which was approximately 2.0 -fold more potent than aqueous layer (48.7\%). Interestingly, the EtOAc-soluble fraction exhibited very potently with $>100 \% \mathrm{sEH}$ activity at the same concentration. Considering that EtOAc-soluble fraction showed the strongest action, our subsequent studies focused on the isolation of active components. This sub-fraction was subjected to column chromatography on a silica gel and C18-RP silica gel column to obtain five compounds $(\mathbf{1}-\mathbf{5})$ (Fig. 1).

Compound $\mathbf{1}$ was obtained as an ivory amorphous powder. The ${ }^{1} \mathrm{H}-\mathrm{NMR}$ of $\mathbf{1}$ showed signals the presence of 1,3,5-trisubstituted benzene ring characterized with $\mathrm{AB}_{2}$ system $\left[\delta_{\mathrm{H}} 6.47(2 \mathrm{H}, \mathrm{d}, J=2.0 \mathrm{~Hz}, \mathrm{H}-2 / \mathrm{H}-6)\right.$ and $6.18(1 \mathrm{H}, \mathrm{t}, J=2.0 \mathrm{~Hz}, \mathrm{H}-4)]$, and a 1,4 -disubstituted benzene ring characterized with an $\mathrm{A}_{2} \mathrm{~B}_{2}$ system $\left[\delta_{\mathrm{H}} 7.36\right.$ $\left(2 \mathrm{H}, \mathrm{d}, J=8.5 \mathrm{~Hz}, \mathrm{H}-2^{\prime} / \mathrm{H}-6^{\prime}\right)$ and $6.78(2 \mathrm{H}, \mathrm{d}, J=8.5 \mathrm{~Hz}$, $\left.\mathrm{H}-3^{\prime} / \mathrm{H}-5^{\prime}\right)$ together with trans-olefinic protons $\left[\delta_{\mathrm{H}} 6.97\right.$ $(1 \mathrm{H}, \mathrm{d}, J=16.0 \mathrm{~Hz}, \mathrm{H}-8)$ and $6.81(1 \mathrm{H}, \mathrm{d}, J=16.0 \mathrm{~Hz}$, H-7)] (Fig. 1). The ${ }^{13} \mathrm{C}-\mathrm{NMR}$ spectrum of 1 exhibited 14 carbon signals including 12 aromatic carbons $\left[\delta_{\mathrm{C}} 102.6-\right.$ 159.6], belonging to two benzene rings, and two olefinic carbons $\left[\delta_{\mathrm{C}} 129.3\right.$ (C-7), and 128.7 (C-8)] (Fig. 1). The ESI-MS data of $\mathbf{1}$ indicated the pseudo molecular ion at $m / z 229.09$ for the $[\mathrm{M}+\mathrm{H}]^{+}$, indicating a molecular weight of 228. Its molecular formula was determined to be $\mathrm{C}_{14} \mathrm{H}_{12} \mathrm{O}_{3}$, according to ESI-MS, ${ }^{1} \mathrm{H}$ - and ${ }^{13} \mathrm{C}$-NMR spectroscopic data. Based on the above evidence and comparison with reported data, ${ }^{26}$ compound $\mathbf{1}$ was identified 


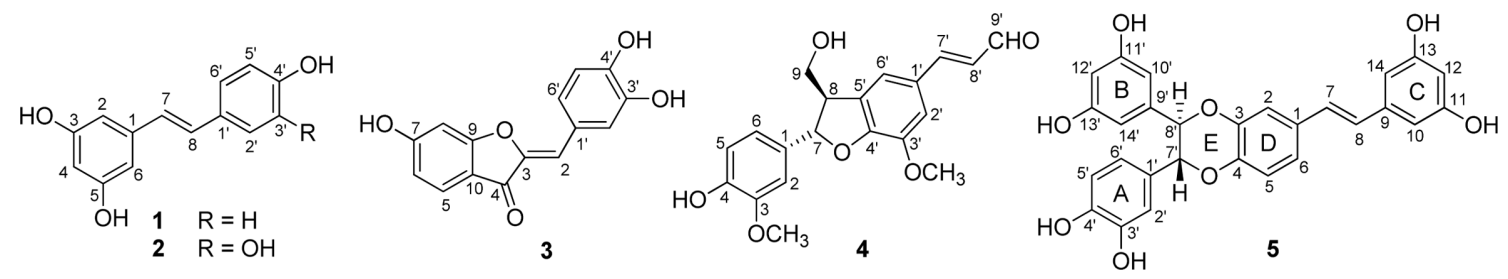

Fig. 1. The structures of isolated compounds $(\mathbf{1}$ - 5) from the seeds of $P$. edulis.

as trans-resveratrol. Compound $\mathbf{2}$, a derivative of $\mathbf{1}$, which the ${ }^{1} \mathrm{H}$ - and ${ }^{13} \mathrm{C}$-NMR spectra were similar to those of 1 except for the presence of 1,3,4-trisubstituted benzene ring characterized with $\mathrm{ABX}$ system $\left[\delta_{\mathrm{H}} 7.07(1 \mathrm{H}, \mathrm{d}\right.$, $\left.J=2.0 \mathrm{~Hz}, \mathrm{H}-2^{\prime}\right), 6.89\left(1 \mathrm{H}, \mathrm{dd}, J=8.5,2.0 \mathrm{~Hz}, \mathrm{H}-6^{\prime}\right)$, and $\left.6.82\left(1 \mathrm{H}, \mathrm{d}, J=8.5 \mathrm{~Hz}, \mathrm{H}-5^{\prime}\right)\right]$ in 2 (Fig. 1). The ESI-MS spectrum of compound $\mathbf{2}$ showed the pseudo molecular ion at $\mathrm{m} / \mathrm{z} 245.08[\mathrm{M}+\mathrm{H}]^{+}$, indicating the molecular formula $\mathrm{C}_{14} \mathrm{H}_{12} \mathrm{O}_{4}$. Thus, compound 2 was identified as trans-piceatannol in comparison with literature data. ${ }^{27}$ These compounds $(\mathbf{1}-\mathbf{2})$ possess the basics of stilbene skeleton and are known to inhibit anti-oxidant, antiinflammatory, anti-diabetes and anticancer. ${ }^{28}$

Compound 3 was obtained as yellow amorphous solid. The ${ }^{1} \mathrm{H}-\mathrm{NMR}$ of $\mathbf{3}$ showed signals of 1,2,4-trisubstituted benzene rings characterized with two $\mathrm{ABX}$ systems $\left[\delta_{\mathrm{H}}\right.$ $7.63(1 \mathrm{H}, \mathrm{d}, J=8.5 \mathrm{~Hz}, \mathrm{H}-5), 7.54(1 \mathrm{H}, \mathrm{d}, J=2.0 \mathrm{~Hz}, \mathrm{H}-$ 8), and $7.26(1 \mathrm{H}, \mathrm{dd}, J=8.5,2.0 \mathrm{~Hz}, \mathrm{H}-6) ; \delta_{\mathrm{H}} 6.86(1 \mathrm{H}$, $\left.\mathrm{d}, J=8.5, \mathrm{~Hz}, \mathrm{H}-5^{\prime}\right), 6.73\left(1 \mathrm{H}, \mathrm{d}, J=2.0 \mathrm{~Hz}, \mathrm{H}-2^{\prime}\right)$, and $\left.6.72\left(1 \mathrm{H}, \mathrm{dd}, J=8.5,2.0 \mathrm{~Hz}, \mathrm{H}-6^{\prime}\right)\right]$, together with an olefinic proton at $\delta_{\mathrm{H}} 6.71(1 \mathrm{H}, \mathrm{s}, \mathrm{H}-2)$ (Fig. 1). The ${ }^{13} \mathrm{C}-$ NMR and distortionless enhancement by polarization transfer (DEPT) spectra of $\mathbf{3}$ showed signals for six aromatic quaternary carbon $\left[\delta_{\mathrm{C}} 169.8(\mathrm{C}-7), 168.4(\mathrm{C}-9)\right.$, 149.3 (C-4'), 146.7 (C-3'), 125.5 (C-1'), 114.8 (C-10)] and six aromatic carbons $\left[\delta_{\mathrm{C}} 126.8(\mathrm{C}-5), 126.3\left(\mathrm{C}-6^{\prime}\right), 118.9\right.$ (C-2'), 116.7 (C-5'), 114.6 (C-6) and 99.3 (C-8)] (Fig. 1). Furthermore, a carbonyl carbon at $\delta_{\mathrm{C}} 184.5(\mathrm{C}-4)$, together with two olefinic carbons $\left[\delta_{\mathrm{C}} 147.7\right.$ (C-3), and 114.1 (C2)] were also observed in the ${ }^{13} \mathrm{C}$ NMR spectrum indicated that 3 was aurone skeleton (Fig. 1). ${ }^{29}$ The ESI-MS spectrum of compound 3 showed the pseudo molecular ion at $m / z 271.06[\mathrm{M}+\mathrm{H}]^{+}$, indicating the molecular formula $\mathrm{C}_{15} \mathrm{H}_{10} \mathrm{O}_{5}$. Based on the above evidence and comparison with reported data, ${ }^{30}$ compound $\mathbf{3}$ was identified as sulfuretin, which was isolated from $P$. edulis for the first time. This compound possessed anti-inflammatory, ${ }^{31}$ anticancer, ${ }^{32}$ and neuroprotective activities. ${ }^{33}$

Compound 4 was isolated as yellow amorphous powder. The ${ }^{1} \mathrm{H}-\mathrm{NMR}$ spectrum of $\mathbf{4}$ showed an aldehyde proton at $\delta_{\mathrm{H}} 9.60\left(1 \mathrm{H}, \mathrm{d}, J=8.0 \mathrm{~Hz}, \mathrm{H}-9^{\prime}\right)$, trans-olefinic protons at $\delta_{\mathrm{H}} 6.70\left(1 \mathrm{H}, \mathrm{dd}, J=15.5,8.0 \mathrm{~Hz}, \mathrm{H}-8^{\prime}\right)$ and $7.61\left(1 \mathrm{H}, \mathrm{d}, J=15.5 \mathrm{~Hz}, \mathrm{H}-7^{\prime}\right)$, which were assigned to a trans-cinnamaldehyde moiety. In addition, the ${ }^{1} \mathrm{H}-\mathrm{NMR}$ of 4 showed two sets of aromatic protons signal $\left[\delta_{\mathrm{H}} 6.97\right.$ $(1 \mathrm{H}, \mathrm{s}, \mathrm{H}-2), 6.85(1 \mathrm{H}, \mathrm{d}, J=8.0 \mathrm{~Hz}, \mathrm{H}-5), 6.80(1 \mathrm{H}, \mathrm{d}$, $J=8.0, \mathrm{H}-6) ; \delta_{\mathrm{H}} 7.31\left(1 \mathrm{H}, \mathrm{s}, \mathrm{H}-6^{\prime}\right), 7.25\left(1 \mathrm{H}, \mathrm{s}, \mathrm{H}-2^{\prime}\right)$ arising from 1,3,4-trisubstituted and 1,3,4,5-tetrasubstituted benzene rings, respectively (Fig. 1). A stereochemistry of the dihydrobenzofuran ring $\left[\delta_{\mathrm{H}} 5.63(1 \mathrm{H}, \mathrm{d}, J=6.5 \mathrm{~Hz}\right.$, $\mathrm{H}-7), \delta_{\mathrm{H}} 3.59(1 \mathrm{H}, \mathrm{q}, J=6.5 \mathrm{~Hz}, \mathrm{H}-8)$ and $\delta_{\mathrm{H}} 3.91-3.87$ $(2 \mathrm{H}, \mathrm{m}, \mathrm{H}-9)]$, and two singlets of methoxy groups $\left[\delta_{\mathrm{H}}\right.$ $3.92\left(3 \mathrm{H}, \mathrm{s}, 3^{\prime}-\mathrm{OCH}_{3}\right)$, and $\left.3.84\left(3 \mathrm{H}, \mathrm{s}, 3-\mathrm{OCH}_{3}\right)\right]$ were also observed in the ${ }^{1} \mathrm{H}-\mathrm{NMR}$ spectrum. The large proton coupling constant between $\mathrm{H}-7$ and $\mathrm{H}-8\left(J_{7,8}=6.5 \mathrm{~Hz}\right)$ suggested the dihydrofuran ring has a trans-configuration. The ${ }^{13} \mathrm{C}-\mathrm{NMR}$ and DEPT spectra of $\mathbf{4}$ revealed the presence of twelve aromatic carbons, two olefinic carbons, an aldehyde carbon $\left[\delta_{\mathrm{C}} 196.1\left(\mathrm{C}^{-}{ }^{\prime}\right)\right]$, a hydroxymethyl carbon $\left[\delta_{\mathrm{C}} 64.5(\mathrm{C}-9)\right]$ and two methoxy carbons $\left[\delta_{\mathrm{C}} 56.8\right.$ $\left(3-\mathrm{OCH}_{3}\right)$, and $\left.56.4\left(3^{\prime}-\mathrm{OCH}_{3}\right)\right]$ (Fig. 1). The $\mathrm{HMBC}$ correlations of proton $\mathrm{H}-2$ at $\delta_{\mathrm{H}} 6.97(1 \mathrm{H}, \mathrm{s})$ and methoxy protons at $\delta_{\mathrm{H}} 3.84(3 \mathrm{H}, \mathrm{s})$ to carbon signal at $\delta_{\mathrm{C}} 149.2(\mathrm{C}-$ 3 ), as well as proton $\mathrm{H}-2$ ' at $\delta_{\mathrm{H}} 7.25(1 \mathrm{H}, \mathrm{s})$ and methoxy protons at $\delta_{\mathrm{H}} 3.92(3 \mathrm{H}, \mathrm{s})$ to carbon signal at $\delta_{\mathrm{C}} 156.1(\mathrm{C}-$ $3^{\prime}$ ), suggested that two methoxy groups were located at C3 and C-3' (Fig. 1). Further analysis of these signals by the COSY, HMQC and HMBC spectra led to the partial structures of 4. The ESI-MS data of $\mathbf{4}$ indicated the pseudo molecular ion at $\mathrm{m} / \mathrm{z} 357.14$ for the $[\mathrm{M}+\mathrm{H}]^{+}$, indicating a molecular weight of 356. Its molecular formula was determined to be $\mathrm{C}_{20} \mathrm{H}_{20} \mathrm{O}_{6}$, according to ESI-MS, ${ }^{1} \mathrm{H}$ - and ${ }^{13} \mathrm{C}-\mathrm{NMR}$ spectroscopic data. Therefore, compound 4 was identified as (+)-balanophonin, ${ }^{34}$ which was isolated from Passiflora genus for the first time. This compound was known to possess anti-oxidant, ${ }^{35,36}$ anticholinesterase, ${ }^{36}$ anti-inflammatory, anticancer, and antineurodegenerative activities. ${ }^{37}$

Compound $\mathbf{5}$ was isolated as brown amorphous powder. The ${ }^{1} \mathrm{H}-\mathrm{NMR}$ spectrum of $\mathbf{5}$ showed the presence of two $\mathrm{ABX}$ system signals for the A ring $\left[\delta_{\mathrm{H}} 6.68(1 \mathrm{H}, \mathrm{d}\right.$, $\left.J=2.0 \mathrm{~Hz}, \mathrm{H}-2^{\prime}\right), 6.67\left(1 \mathrm{H}, \mathrm{d}, J=8.5 \mathrm{~Hz}, \mathrm{H}-5^{\prime}\right), 6.50(1 \mathrm{H}$, 
$\left.\left.\mathrm{dd}, J=8.5,2.0 \mathrm{~Hz}, \mathrm{H}-6^{\prime}\right)\right]$ and the D ring $\left[\delta_{\mathrm{H}} 7.15(1 \mathrm{H}, \mathrm{d}\right.$, $J=2.0 \mathrm{~Hz}, \mathrm{H}-2), 7.09(1 \mathrm{H}, \mathrm{dd}, J=8.5,2.0 \mathrm{~Hz}, \mathrm{H}-6), 6.96$ $(1 \mathrm{H}, \mathrm{d}, J=8.5 \mathrm{~Hz}, \mathrm{H}-5)]$, two sets of $\mathrm{AB}_{2}$ system signals for the $\mathrm{B}$ and $\mathrm{C}$ rings $\left[6.48\left(2 \mathrm{H}\right.\right.$, overlap, $\left.\mathrm{H}-12 / \mathrm{H}-12^{\prime}\right)$, $\left.6.19(1 \mathrm{H}, \mathrm{t}, J=2.0 \mathrm{~Hz}, \mathrm{H}-14)^{\prime}\right), 6.17(1 \mathrm{H}, \mathrm{t}, J=2.0 \mathrm{~Hz}, \mathrm{H}-$ $\left.\left.10^{\prime}\right), 6.12(2 \mathrm{H}, \mathrm{d}, J=2.0 \mathrm{~Hz}, \mathrm{H}-10 / \mathrm{H}-14)\right]$, two doublets for the trans-olefinic protons $\left[\delta_{\mathrm{H}} 6.99(1 \mathrm{H}, \mathrm{d}, J=16.0 \mathrm{~Hz}\right.$, $\mathrm{H}-7), 6.88(1 \mathrm{H}, \mathrm{d}, J=16.0 \mathrm{~Hz}, \mathrm{H}-8)]$, and two equivalent oxybenzyl methine protons $\left[\delta_{\mathrm{H}} 4.75(2 \mathrm{H}, \mathrm{d}, J=2.5 \mathrm{~Hz}\right.$, H-7'/H-8')] (Fig. 1). The ${ }^{13} \mathrm{C}-\mathrm{NMR}$ and DEPT spectra of 5 exhibited 28 carbon signals including 24 aromatic carbons [ $\left.\delta_{\mathrm{C}} 102.9-159.6\right]$, belonging to four benzene rings, and two olefinic carbons $\left[\delta_{\mathrm{C}} 129.4(\mathrm{C}-7)\right.$, and $\left.128.4(\mathrm{C}-8)\right]$. In addition, the carbon signals $\left[\delta_{\mathrm{C}} 82.2\left(\mathrm{C}-8^{\prime}\right)\right.$ and $81.8(\mathrm{C}-$ $\left.7^{\prime}\right)$ ] indicate the presence of two equivalent oxybenzyl methine carbons. Analysis of these signals by the COSY, HMQC and HMBC spectra led to the partial structures of compound 5 (Fig. 1). The ESI-MS data of 5 indicated the pseudo molecular ion at $\mathrm{m} / \mathrm{z} 487.13$ for the $[\mathrm{M}+\mathrm{H}]^{+}$, indicating a molecular weight of 486. Its molecular formula was determined to be $\mathrm{C}_{28} \mathrm{H}_{22} \mathrm{O}_{8}$, according to ESI-MS, ${ }^{1} \mathrm{H}-$ and ${ }^{13} \mathrm{C}-\mathrm{NMR}$ spectroscopic data. The relative configuration between the $\mathrm{C}-7^{\prime}$ and the $\mathrm{C}-8^{\prime}$ positions was concluded to be cis from the coupling constant of the two oxybenzylmethine protons $(J=2.5$ $\mathrm{Hz}$ ). Based on the above evidence and comparison with reported data, ${ }^{38}$ compound $\mathbf{5}$ was identified as cassigarol E, which was isolated from Passiflora genus for the first time. Cassigarol E possessed anti-HIV-1, ${ }^{39}$ antidiabetic, ${ }^{40}$ and anticancer activities. ${ }^{41}$

The effect of isolated compounds $(\mathbf{1}-\mathbf{5})$ from $P$. edulis on sEH inhibitory activities was evaluated. The sEH inhibitory activities were determined using recombinant human SEH incubated with PHOME, an artificial substrate for fluorescence detection with AUDA $\left(\mathrm{IC}_{50}\right.$ value 4.4 $\mathrm{nM})$, a sEH inhibitor as the positive control. The result showed that compound $\mathbf{4}$ had no inhibitory (N.I) effect on the activity of enzyme sEH at a concentration of $100 \mu \mathrm{M}$, while compounds $\mathbf{1}$ and $\mathbf{2}$ at a concentration of $100 \mu \mathrm{M}$ exhibited the highest sEH inhibitory activity $(>100 \%)$ (Table 1). Sulfuretin (3), and cassigarol E (5) also showed a strong inhibitory effect on sEH with their inhibition values in the range of 74.6 and $77.7 \%$, respectively (Table 1). Compounds $\mathbf{1}$ - 3, and 5 showed inhibitory rates over $50 \%$ and were further evaluated at concentrations ranging from 6.2 to $100 \mu \mathrm{M}$, to elucidate the $\mathrm{IC}_{50}$ values. These inhibitors (1 - 3, and 5) showed dose-dependent inhibition, with $\mathrm{IC}_{50}$ values of $14.2 \pm 0.6,3.4 \pm 4.8,15.8 \pm 1.0$, and $14.4 \pm 0.8 \mu \mathrm{M}$, respectively (Table 2 ).

Previously, natural plant components with stilbene
Table 1. Effects of extracts of $P$. edulis on sEH inhibitory activity

\begin{tabular}{cccc}
\hline \hline \multirow{2}{*}{ Fractions } & \multicolumn{3}{c}{${\text { Inhibition rate }(\%)^{a}}^{a}$} \\
\cline { 2 - 4 } & $37.5 \mu \mathrm{g} / \mathrm{mL}$ & $75 \mu \mathrm{g} / \mathrm{mL}$ & $150 \mu \mathrm{g} / \mathrm{mL}$ \\
\hline EtOH & $64.7 \pm 0.4$ & $97.9 \pm 0.7$ & $>100$ \\
$\mathrm{CH}_{2} \mathrm{Cl}_{2}$ & $91.8 \pm 3.3$ & $95.4 \pm 0.4$ & $>100$ \\
EtOAc & $>100$ & $>100$ & $>100$ \\
Aqueous layer & $48.7 \pm 0.9$ & $61.8 \pm 2.2$ & $71.5 \pm 1.5$ \\
\hline
\end{tabular}

${ }^{a}$ Extracts and fractions were tested three times.

Table 2. The sEH inhibitory activities of isolated compounds from $P$. edulis

\begin{tabular}{ccc}
\hline \hline Compound & $100 \mu \mathrm{M}(\%)$ & $\mathrm{IC}_{50}$ value $(\mu \mathrm{M})^{a}$ \\
\hline $\mathbf{1}$ & $>100$ & $14.2 \pm 0.6$ \\
$\mathbf{2}$ & $>100$ & $3.4 \pm 4.8$ \\
$\mathbf{3}$ & $74.6 \pm 0.4$ & $15.8 \pm 1.0$ \\
$\mathbf{4}$ & N.I & N.T \\
$\mathbf{5}$ & $77.7 \pm 1.3$ & $14.4 \pm 0.8$ \\
AUDA $^{b}$ & $68.9 \pm 0.3$ & $4.4 \pm 0.1(\mathrm{nM})$ \\
\hline
\end{tabular}

N.T: Not tested.

N.I: Not inhibition.

${ }^{\text {a }}$ Compounds were tested three times.

${ }^{\mathrm{b}}$ AUDA was used as a positive control.

skeletons from other plants have also shown inhibitory effects on sEH activity. Rhapontigenin, isorhapontin and astringin from Rheum undulatum (Polygonaceae), ${ }^{8}$ and 2isopropyl-5-[(E)-2- phenylvinyl]benzene-1,3-diol have displayed potent sEH inhibitory activity. ${ }^{42}$ Several stilbene from Polygonum multiflorum (Polygonaceae), such as $(E)-2,3,5,4$ '-tetrahydroxystilbene-2- $O$ - $\beta$-D-glucoside, $(E)$ $2,3,5,4$-tetrahydroxystilbene-2- $O-\beta$-D-xyloside, and $(E)$ $2,3,5,4$ '-tetrahydroxystilbene-2- $O-\beta$-D-(6"-O-acetyl)-glucoside completely inhibited $\mathrm{sEH}$ in a dose-dependent manner, with low $\mathrm{IC}_{50}$ values. ${ }^{43}$ As in this study, some isolated stilbenes from $P$. edulis can manifest sEH inhibitory activity. Such compounds have been purified from natural medicinal plants for many years all over the world. In addition to other medicinal properties, such as anti-inflammatory, anticancer, and antioxidant activities, the sEH inhibitory activity is worthy of notice, because low-molecular-weight materials can easily reach the site of action following oral administration since they cross the blood-brain barrier. ${ }^{44}$

\section{Acknowledgments}

We would like to thank Vietnam Academy of Science and Technology (VAST), Vietnam for financial support (under grand No. VAST.CTG.03/17-18) and Nafoods Group JSC for providing materials. 


\section{References}

(1) Morisseau, C.; Hammock, B. D. Annu. Rev. Pharmacol. Toxicol. 2013, 53, 37-58.

(2) Morisseau, C.; Inceoglu, B.; Schmelzer, K.; Tsai, H. J.; Jinks, S. L.; Hegedus, C. M.; Hammock, B. D. J. Lipid Res. 2010, 51, 3481-3490.

(3) Lin, W. K.; Falck, J. R.; Wong, P. Y. Biochem. Biophys. Res. Commun. 1990, 167, 977-981.

(4) Inceoglu, B.; Jinks, S. L.; Schmelzer, K. R.; Waite, T.; Kim, I. H.; Hammock, B. D. Life Sci. 2006, 79, 2311-2319.

(5) Yu, Z.; Xu, F.; Huse, L. M.; Morisseau, C.; Draper, A. J.; Newman, J. W.; Parker, C.; Graham, L.; Engler, M. M.; Hammock, B. D.; Zeldin,

D. C.; Kroetz, D. L. Circ. Res. 2000, 87, 992-998.

(6) Kim, J. H.; Tai, B. H.; Yang, S. Y.; Kim, J. E.; Kim, S. K.; Kim, Y. H. Bull. Korean Chem. Soc. 2015, 36, 300-304.

(7) Kim, J. H.; Cho, C. W.; Tai, B. H.; Yang, S. Y.; Choi, G. S.; Kang, J. S.; Kim, Y. H. Molecules 2015, 20, $21405-21414$.

(8) Jo, A. R.; Kim, J. H.; Yan, X. T.; Yang, S. Y.; Kim, Y. H. J. Enzyme Inhib. Med. Chem. 2016, 31, 70-78.

(9) Lee, G. Y.; Kim, J. H.; Choi, S. K.; Kim, Y. H. Bioorg. Med. Chem. Lett. 2015, 25, 5097-5101.

(10) Kim, J. H.; Morgan, A. M. A.; Tai, B. H.; Van, D. T.; Cuong, N. M.; Kim, Y. H. J. Enzyme Inhib. Med. Chem. 2016, 31, 640-644.

(11) Khanh, P. N.; Duc, H. V.; Huong, T. T.; Son, N. T.; Ha, V. T.; Van, D. T.; Tai, B. H.; Kim, J. E.; Jo, A. R.; Kim, Y. H.; Cuong, N. M. Fitoterapia 2016, 109, 39-44.

(12) Thokchom, R.; Mandal, G. J. Agric. Eng. Food Technol. 2017, 4, 27-30.

(13) Beninca, J. P.; Montanher, A. B.; Zucolotto, S. M.; Schenkel, E. P.; Frode, T. S. Food Chem. 2007, 104, 1097-1105.

(14) Ichimura, T.; Yamanaka, A.; Ichiba, T.; Toyokawa, T.; Kamada, Y.; Tamamura, T.; Maruyama, S. Biosci. Biotechnol. Biochem. 2006, 70, 718721.

(15) Lourith, N.; Kanlayavattanakul, M. J. Oleo Sci. 2013, 64, 235-240.

(16) Puricelli, L.; Dell'Aica, I.; Sartorb, L.; Garbisa, S.; Caniato, R. Fitoterapia 2003, 74, 302-304.

(17) Coleta, M.; Campos, M. G.; Cotrim, M. D.; Proenca da Cunha, A. Pharmacopsychiatry 2001, 34, S20-S21.

(18) Pelegrini, P. B.; Noronha, E. F.; Muniz, M. A.; Vasconcelos, I. M.; Chiarello, M. D.; Oliveira, J. T.; Franco, O. L. Biochim. Biophys. Acta. 2006, 1764, 1141-1146.

(19) Matsui, Y.; Sugiyama, K.; Kamei, M.; Takahashi, T.; Suzuki, T.; Katagata, Y.; Ito, T. J. Agric. Food Chem. 2010, 58, 11112-11118.

(20) Bombardelli, E.; Bonati, A.; Gabetta, B.; Martinelli, E. M.; Mustich, G.; Danieli, G. Phytochemisty 1975, 14, 2661-2665.

(21) Mareck, U.; Herrmann, K.; Galensa, R.; Wray, V. Phytochemistry 1991, 30, 3486-3487.

(22) Seigler, D. S.; Pauli, G. F.; Nahrstedt, A.; Leen, R. Phytochemistry 2002, 60, 873-882.

(23) Pereira, C. A.; Yariwake, J. H.; Lancas, F. M.; Wauters, J. N.; Tits, M.; Angenot, L. Phytochem. Anal. 2004, 15, 241-248.
(24) Sano, S.; Sugiyama, K.; Ito, T.; Katano, Y.; Ishihata, A. J. Agric. Food Chem. 2011, 59, 6209-6213.

(25) Piombo, G.; Barouh N.; Barea, B.; Boulanger, R.; Brat, P.; Pina, M.; Villeneuve, P. OCL 2006, 13, 195-199.

(26) Mattivi, F.; Reniero, F.; Korhammer, S. J. Agric. Food Chem. 1995, 43, 1820-1823.

(27) Mathi, P.; Das, S.; Nikhil, K.; Roy, P.; Yerra, S.; Ravada, S. R.; Bokka, V. R.; Botlagunta, M. Int. J. Prev. Med. 2015, 6, 101.

(28) Kukreja, A.; Wadhwa, N.; Tiwari, A. J. Blood Disord. Transfus. 2014, 5, 240 .

(29) Gaur, R.; Kumar, S.; Trivedi, P.; Bhakuni, R. S.; Bawankule, D. U.; Pal, A.; Shanker, K. Nat. Prod. Commun. 2010, 5, 1243-1246.

(30) Júnior, G. M. V.; Sousa, C. M. M.; Cavalheiro, A. J.; Lago, J. H. G.; Chaves, M. H. Helv. Chim. Acta 2008, 91, 2159-2167.

(31) Lee, D. S.; Jeong, G. S.; Li, B.; Park, H.; Kim, Y. C. Int. Immunopharmacol. 2010, 10, 850-858.

(32) Lee, K. W.; Chung, K. S.; Seo, J. H.; Yim, S. V.; Park, H. J.; Choi, J. H.; Lee, K. T. J. Cell. Biochem. 2012, 113, 2835-2844.

(33) Pariyar, R.; Lamichhane, R.; Jung, H. J.; Kim, S. Y.; Seo, J. Int. J. Mol. Sci. 2017, 18, E2753.

(34) Li, J. L.; Li, N.; Xing, S. S.; Zhang, N.; Li, B. B.; Chen, J. G.; Ahn, J. S.; Cui, L. Arch. Pharm. Res. 2017, 40, 1265-1270.

(35) Esposito, T.; Sansone, F.; Franceschelli, S.; Del Gaudio, P.; Picerno, P.; Aquino, R. P.; Mencherini, T. Int. J. Mol. Sci. 2017, 18, E392.

(36) Boğa, M.; Yilmaz, P. K.; Cebe, D. B.; Fatima, M.; Siddiqui, B. S.; Kolak, U. Z. Naturforsch C J. Biosci. 2014, 69, 381-390.

(37) Lim, S. Y.; Subedi, L.; Shin, D.; Kim, C. S.; Lee, K. R.; Kim, S. Y. Biomol. Ther 2017, 25, 519-527.

(38) Baba, K.; Kido, T.; Taniguchi, M.; Kozawaqa, M. Phytochemistry 1994, 36, 1509-1513.

(39) Bunluepuech, K.; Wattanapiromsakul, C.; Tewtrakul, S. Songklanakarin J. Sci. Technol. 2013, 35, 665-669.

(40) Tran, H. H. T.; Nguyen, M. C.; Le, H. T.; Nguyen, T. L.; Pham, T. B.; Chau, V. M.; Nguyen, H. N.; Nguyen, T. D. Pharm. Biol. 2014, 52, 74-77.

(41) Yuenyongsawad, S.; Bunluepuech, K.; Wattanapiromsakul, C.; Tewtrakul, S. Songklanakarin J. Sci. Technol. 2014, 36, 189-194.

(42) Buscató, E.; Büttner, D.; Brüggerhoff, A.; Klingler, F. M.; Weber, J.; Scholz, B.; Zivković, A.; Marschalek, R.; Stark, H.; Steinhilber, D.; Bode, H. B.; Proschak, E. ChemMedChem 2013, 8, 919-923.

(43) Sun, Y. N.; Li, W.; Kim, J. H.; Yan, X. T.; Kim, J. E.; Yang, S. Y.; Kim, Y. H. Arch. Pharm. Res. 2015, 38, 998-1004.

(44) Broadwell, R. D.; Sofroniew, M. V. Exp. Neurol. 1993, 120, $245-$ 263

Received August 28, 2019

Revised October 17, 2019

Accepted October 21, 2019 